Volume 3, Issue 2, pages 185-202

\title{
The Simulation of Traffic Signal Preemption using GPS and Dijkstra Algorithm for Emergency Fire Handling at Makassar City Fire Service
}

\author{
M. Friaswanto ${ }^{1}$, E. A. Lisangan ${ }^{1, *}$, S. C. Sumarta ${ }^{1}$ \\ ${ }^{1}$ Department of Information Technology, Atma Jaya University of \\ Makassar, Indonesia \\ *Corresponding Author: erick_lisangan@lecturer.uajm.ac.id
}

(Received 04-11-2021; Revised 28-12-2021; Accepted 28-12-2021)

\begin{abstract}
The Makassar City Fire Department often faces obstacles in handling fires. Problems that often hinder such as congestion at crossroads, panic residents, and others. The result of this research is a system that can assist firefighters when handling fire cases in terms of accelerating the firefighting team to the location of the fire. Dijkstra's algorithm will be used to find the shortest path to the fire location and the travel time. Then the traffic signal preemption simulation adjusts the color of the lights when the GPS vehicle approaches the traffic lights on the path to be traversed. The simulation results show that the use of traffic signal preemption in collaboration with Dijkstra's algorithm and GPS can help the performance of the Makassar City Fire Department, especially for handling fires that require fast time.
\end{abstract}

Keywords: Fire service, traffic signal preemption, GPS simulation, Dijkstra algorithm 


\section{International Journal of Applied Sciences and Smart Technologies}

Volume 3, Issue 2, pages 185-202

p-ISSN 2655-8564, e-ISSN 2685-9432

\section{Introduction}

Based on report data obtained from the Makassar City Fire Service, in the Makassar city area in 2018 there were 209 incidents spread across 14 sub-districts. Where from 209 fire cases that occurred throughout 2018 in the city of Makassar there were losses estimated at around Rp. 22,040,000,000 and 10 people died due to fire and 7 people were injured. Realizing the dangers of fire, a Fire Department has been established in every region of Indonesia, including Makassar city, in order to prevent and overcome fires that can occur at any time. When a fire occurs, firefighters must always be ready to handle and extinguish the fire. But usually to deal with fires before the firefighters arrive, the community usually works together to extinguish the fire manually while helping the victim. But obviously very difficult if the fire has grown and the wind is strong. Therefore the presence of a fire extinguisher is very necessary.

Based on the results of the author's interview with one of the Makassar City Fire Department officers, there are several problems that can interfere with or hinder the performance of officers. The problems commonly faced by the Makassar City Fire Department when dealing with fires are road congestion and also at traffic light intersections, the fastest route to the fire location, information that is slow to receive, residents and journalists covering which hinder the work of officers, citizens who are always willing use extinguishing equipment to help but do not even know the function of the tool, and so on. These problems can certainly cause harm to the victim. This makes every minute very valuable in fire fighting.

The problem of congestion and traffic lights are also things that can interfere with the performance of the Makassar City Fire Department. Whereas based on the Regulation of the Minister of Public Works No. 20 of 2009, the emergency response time for fires in Indonesia should not be more than 15 minutes after receiving notification of a fire in a location $7.5 \mathrm{~km}$ from the nearest fire station. For the Makassar City area, there are 7 fire stations scattered in several places in the Makassar city area. The problem of congestion and traffic conditions at crossroads with traffic lights were also complained of by firefighters interviewed by researchers. When the fire engine is on a road that is in a traffic jam, the fire engine is forced to reduce the speed of the vehicle and make the 


\section{International Journal of Applied Sciences and Smart Technologies}

Volume 3, Issue 2, pages 185-202

p-ISSN 2655-8564, e-ISSN 2685-9432

firefighters late to the fire location, resulting in delays in handling fires and can result in more losses. Even though they have the right to break through traffic lights or take the opposite lane, firefighters are also often hampered at intersections if the traffic light is still red and cannot move to the opposite lane.

For the problem of finding a route for fire trucks to get to the fire location so far at the Makassar City Fire Department, it is still based on the knowledge of the team leader and other officers in charge of extinguishing the fire, and when there is an obstacle on the road, the team leader must be able to find alternative routes for his team to fire location. One of the algorithms that can be used to find the shortest route is Dijkstra's algorithm. Dijkstra's algorithm is an algorithm invented by Edsger W. Dijkstra and published in 1959. This algorithm is used to solve the shortest path problem for a directed graph. This algorithm finds the shortest path from the starting point to the end point based on the smallest weight from one point to another. The way the Dijkstra algorithm works uses a greedy strategy, where at each step the side with the smallest weight is selected that connects a node that has been selected with another node that has not been selected [1], [2]. The results of the Dijkstra's algorithm will be used as directions for Makassar city firefighters when heading to the fire location. To find the shortest path to the fire location, the Dijkstra algorithm method is used where the weight values to be used are the distance of each node and the value of traffic density.

Several previous studies have examined the search for the shortest route as in [3], [4], [5], [6]. Ratnasari et al (2013) concluded that Dijkstra's algorithm can produce a simulation of the shortest path along with alternative paths and the travel time required for a vehicle to reach a certain location. Iswanjono and Wijaya (2015) designed an automatic system to regulate traffic lights at crossroads. This automatic system works after a vehicle that has a special priority to go through a red light sends GPS coordinates via radio waves which will later be captured by a receiver mounted on a traffic light. Aquarizky et al (2017) concluded that the Floyd-Warshall Algorithm can be used to find the shortest route for firefighters, but it has not been integrated with congestion data and red light settings in real time. In addition, this algorithm is also not appropriate to be used in a wide area because the suggested results are not optimal. Septifany et al (2017) compared finding the optimum route with the Dijkstra's algorithm method and the A* 


\section{International Journal of Applied Sciences and Smart Technologies}

Volume 3, Issue 2, pages 185-202

p-ISSN 2655-8564, e-ISSN 2685-9432

algorithm. The results of this comparison state that there is no significant difference between the two. In addition, the suitability of the route obtained from the routing process using PostgreSQL, is still less accurate than the route generated by Google Maps. Due to incomplete road shape file data such as those owned by Google Maps and PostgreSQL, it is not equipped with weighting for traffic directions. As a result, there are routes that cannot be used due to inappropriate road taking. In this study, the determination of the shortest route is only based on the distance between nodes and no weight is given to traffic conditions that will be traversed by firefighters.

Several developed countries have implemented Traffic Signal Preemption / Traffic Signal Priorization to regulate traffic lights so that vehicles that have priority to pass through the road will be given a road. If the vehicle that has priority will pass then the light will be green and the surroundings will be red. This can be used to allow vehicles handling emergency vehicles to pass through the road by turning the light green. This light change can help emergency vehicles to arrive at the location faster and increase safety when heading to the fire location [7]. One method that can be used to implement traffic signal preemption is to use the Global Positioning System or GPS [8]. The Global Positioning System (GPS) is a radio navigation system using 24 satellites orbiting the earth in 6 circular orbits. Where all units can transmit signals to earth and later will be captured by the signal receiver. This GPS system was originally developed by the US Department of Defense in the early 80s [9].

Meanwhile, to design Traffic Signal Preemption / Traffic Signal Priorization, it is simply made using Wemos D1. In this simulation, the GPS simulation is set using JavaScript to coordinate the vehicle that will go to the location of the fire. And when the fire department vehicle starts to go to the fire location, the simulation of the GPS coordinates of the fire squad vehicle will start to be compared with the coordinates of the nearest traffic light on the path that the fire fighting vehicle will take when heading to the fire location. The nearest traffic light will turn green on the path to be traversed in order to give priority to firefighter vehicles so that every vehicle on the path to be passed by the firefighters will run so that there is no accumulation of vehicles on the path that will be traversed by fire vehicles to the location of the fire. When the traffic 


\section{International Journal of Applied Sciences and Smart Technologies}

Volume 3, Issue 2, pages 185-202

p-ISSN 2655-8564, e-ISSN 2685-9432

light has been passed, the traffic light will return to its normal status, while the next nearest traffic light will be a priority until the fire engine passes.

\section{Research Methodology}

\section{Research design}

The design method used is the Waterfall method (Figure 1) which consists of analysis, design, writing, testing, and implementation and maintenance. The data collection method used by the author in this research is to use literature studies and interviews. The literature study used in the study to collect data on traffic signal preemption, Wemos and the Ddijkstra algorithm obtained from various reference sources, books, offline and online journals. Interviews were used to obtain information by asking questions directly to the resource persons, namely the Makassar City Fire Department.

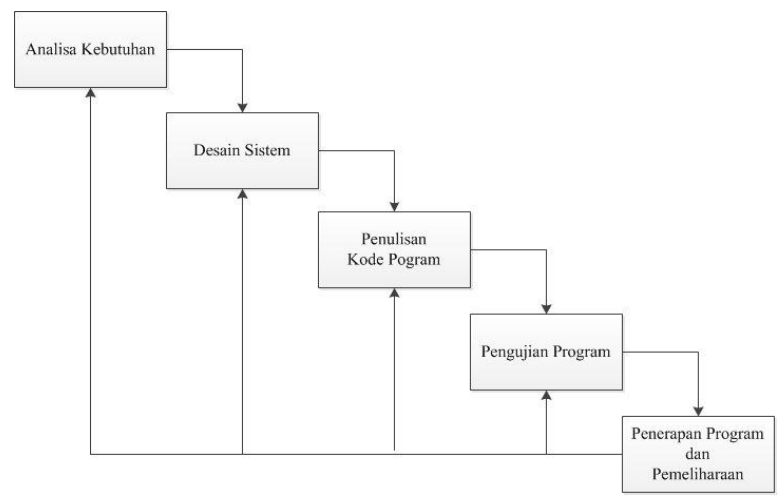

Figure 1. Waterfall's method [10]

The author has conducted an interview process with the Makassar city fire department to find out the problems faced by firefighters when carrying out their duties to extinguish fires. From the interviewer, it was concluded that the Makassar City Fire Department currently requires a system that is able to display the path to the location of the fire from the Pemadam Headquarters, as well as a traffic light control system to assist fire trucks to the location of the fire. 


\section{International Journal of Applied Sciences and Smart Technologies}

Volume 3, Issue 2, pages 185-202

p-ISSN 2655-8564, e-ISSN 2685-9432

\section{Traffic Light Simulation Circuit}

The traffic signal preemption simulation requires a digital traffic light circuit. The traffic light simulation circuit can be seen in Figure 2. In Figure 2 it can be seen that the circuit consists of several components, namely Wemos, traffic light module, and I2C LCD. The Wemos board is used as a microcontroller whose job is to control the lights that will be turned on at traffic lights based on the information received from the server. Communication between Wemos and the server uses the internet which is connected via the ESP8266 Wifi module on Wemos. In addition, the I2C LCD is an information display on the traffic light to provide information to motorists that the fire engine will pass through the area around the traffic light so that the driver can pull over to make room for the fire engine.

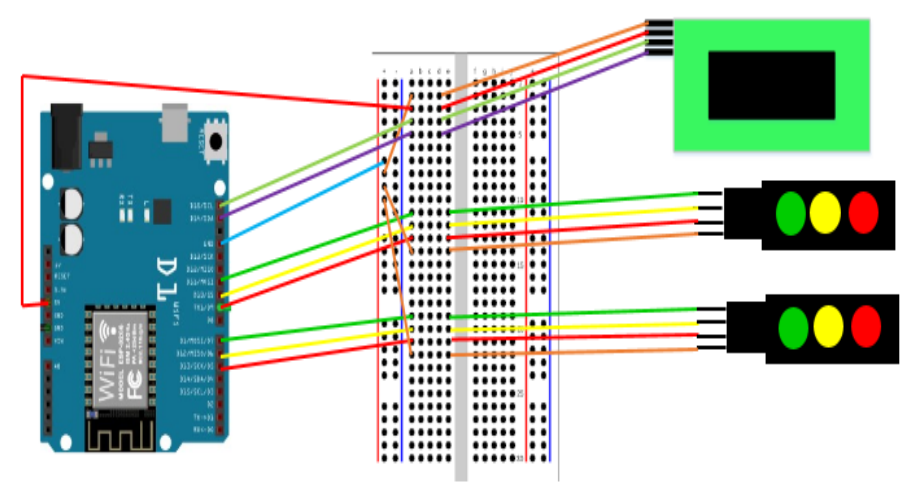

Figure 2. Traffic light simulation circuit

\section{Results and Discussion}

\section{Traffic Signal Preemption Algorithm Design}

In the calculation of the Dijkstra algorithm, it is necessary to have a weight for each related node, in this study the weight is taken from the distance of each node in meters and the value of traffic density where the value is randomly generated assuming a value range of 0 to 100 . The limit value is 100 . selected with the assumption that a road segment can accommodate a maximum of 100 vehicles at one time, so that when the density value is above 75 it will be categorized as a moderately dense vehicle. The distance of each node along with the value of traffic density will be summed and will be 


\section{International Journal of Applied Sciences and Smart Technologies}

Volume 3, Issue 2, pages 185-202

p-ISSN 2655-8564, e-ISSN 2685-9432

the main weight used in Dijkstra's algorithm.

The results of the algorithm in the form of path, distance, and time of the vehicle will be displayed on the map. Based on the distance obtained, the travel time will also be calculated with a standard speed of $40 \mathrm{~km} /$ hour or 666.67 meters/minute. For traffic light settings, the coordinates of the vehicle will be calculated the distance to the traffic light on the path to be traversed. The traffic light that will be traversed and closest to the vehicle will turn green, and when the vehicle has passed the traffic light, the light will return to normal. Then if the fire has been handled, a fire case report will be included. The flowchart of the traffic signal preemption system simulation can be seen in Figure 3.
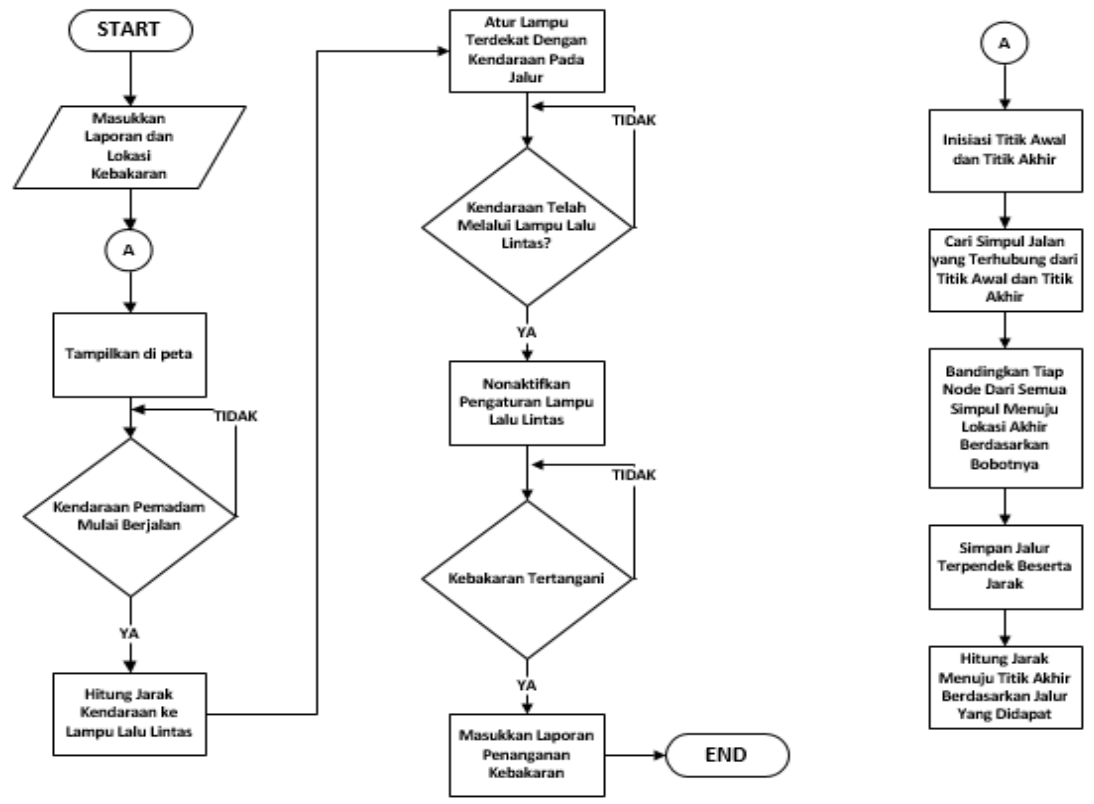

Figure 3. Flowchart of Traffic Signal Preemption system simulation

\section{System Workflow}

Figure 4 illustrates the workflow of the system mechanism for the fire brigade. Fire location information in the form of distance and travel time to the location will be received by the fire brigade. Furthermore, when the firefighters will leave for the location of the fire, the leader of the firefighting team will press the "Depart" button when the vehicle will go to the location of the fire. And when the vehicle moves, the coordinates will be sent to the system to calculate the distance from the vehicle to the nearest traffic light on a predetermined path. When a nearby light is found it will be set to green to give priority to the fire department. When the firefighters 


\section{International Journal of Applied Sciences and Smart Technologies}

Volume 3, Issue 2, pages 185-202

p-ISSN 2655-8564, e-ISSN 2685-9432

have arrived at the location, the team leader can turn off the map and when the fire is finished, the fire team leader can send information that the fire has been handled.

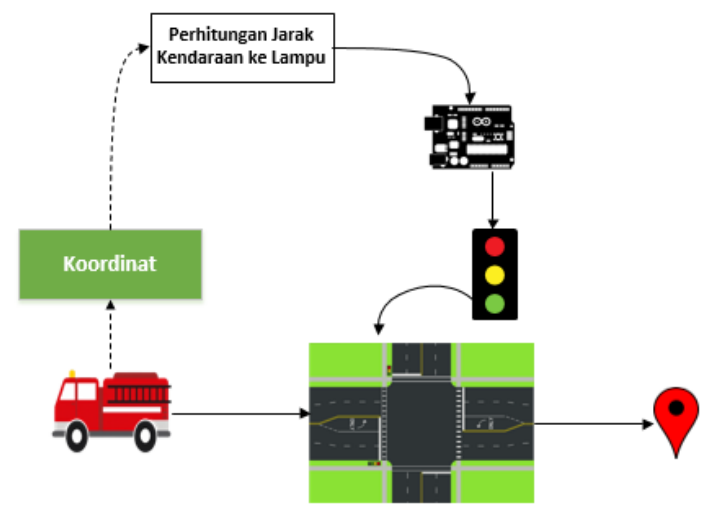

Figure 4. Fire Squad System Workflow

\section{Graph Representation}

To form a graph of a real road, the latitude and longitude coordinates of each road is needed along with the distance of each road. To form a graph from geolocation data, the nodes/points of each location must first be determined. After that the nodes will be connected. A node can be connected to several nodes at once, it will form a node which will later form a graph. In this study, researchers used 103 nodes to connect 45 road points in the Makassar city area adjacent to the fire station on Jalan Ratulangi with a total of 190 nodes (Figure 5).

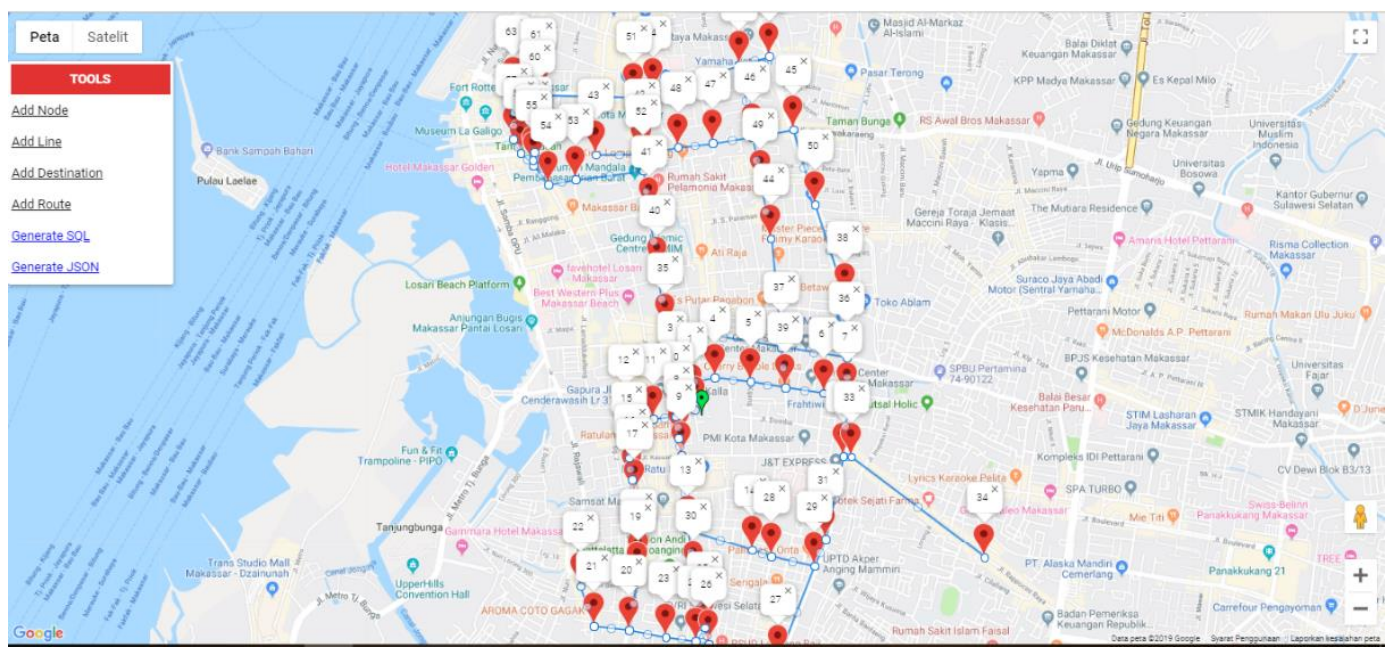

Figure 5. Graph representation of several Makassar city roads 


\section{International Journal of Applied Sciences and Smart Technologies}

Volume 3, Issue 2, pages 185-202

p-ISSN 2655-8564, e-ISSN 2685-9432

\section{The Implementation of Dijkstra's Algorithm}

The process of Dijkstra's algorithm in the system is carried out by determining the starting point and ending point to be processed. The starting point/departure point used is the Makassar city fire station, namely at coordinates -5.149009661835451, 119.4167173586253 or at the Fire Department on Ratulangi road, while the end point is the coordinates of the road where a fire will occur. For the weight on a road is obtained from the length or distance of each interconnected node and from the value of traffic density where the value ranges from 0 to 100 where this value is assumed to be the number of vehicles at a road point.

For selected waypoints to be given a certain weight at 16:00-16:30. Meanwhile, at times other than these hours, the value of traffic density will be randomly generated at each road point so that it can generate several possible paths. When the value of traffic density on a road is higher, this value will affect the process of finding the shortest path. From the departure point, each neighbor point that has not been passed will be considered and then the weight will be calculated. For example, suppose the distance from point $\mathrm{A}$ to point $\mathrm{B}$ is smaller than the distance from point $\mathrm{A}$ to $\mathrm{C}$ then the data $\mathrm{A}$ to $\mathrm{B}$ will be stored. If then there is a smaller distance then the old data will be deleted and replaced with new data. Each node/point that has been passed will not be calculated again for that point. Then the point that has not been traversed with the smallest distance (from the departure node) will be set as a new departure node.

Determination of the shortest path calculated using the Dijkstra algorithm will produce the shortest path along with the travel time that can be traversed by fire fighting vehicles when heading to the fire location. Then for the traffic lights in the city of Makassar, most of them are still analog or manual where at the traffic lights a timer is installed to change the color of the lights in under 1 minute. The lights are unresponsive and cannot adapt to crossing conditions.

The use of a microcontroller can be used to change the status of the lights when the vehicle is on the vehicle path to be traversed. For the change of lights, when the firefighters enter the map display page, the GPS simulation will start running and will start sending the coordinates of the traffic lights on the path that has been obtained in the results of the Dijkstra algorithm which will be a priority for the firefighters who will 


\section{International Journal of Applied Sciences and Smart Technologies}

Volume 3, Issue 2, pages 185-202

p-ISSN 2655-8564, e-ISSN 2685-9432

be tasked with extinguishing the fire. . Then when the fire engine has passed the traffic light coordinates, the lights will automatically return to normal status.

In this simulation, the search for the shortest path and traffic light settings is carried out when the fire engine is heading to the location of the fire. The location point that will be used is on Jalan Panampu, where in the results of the interview there is information that there has been a delay in getting to the location of the fire. The delay limit used by the author is based on the Regulation of the Minister of Public Works No. 20 of 2009, where the emergency response time for fires in Indonesia should not be more than 15 minutes after receiving notification of a fire in a location $7.5 \mathrm{~km}$ from the nearest fire station.

To search for the shortest path, there are two simulations, namely simulations around 16:00-16:30 and outside these times (Figure 6). In the hours outside 16:00-16:30 there are several possible paths that can be passed. However, a route with the shortest distance will be sought from the Pemadam Headquarters to Jalan Panampu along with the travel time to the location of the fire at a standard speed of $40 \mathrm{~km} / \mathrm{hour}$ or 666.67 meters/minute.
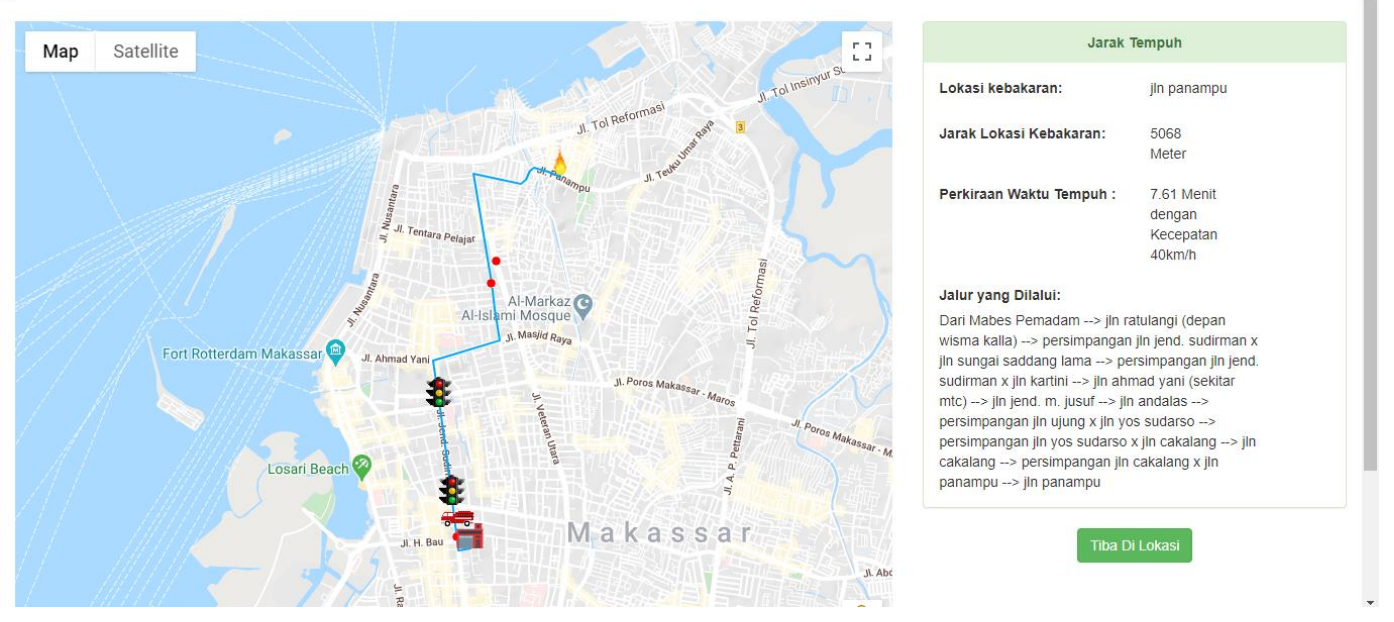

Figure 6. Route search results at 16:00-16:30

From the results of the path search by the Dijkstra algorithm at 16:00-16:30, the distance to the fire location on Jalan Panampu is 5068 meters with an estimated path and travel time of 7 minutes to get to the location of the fire on Jalan Panampu and 


\section{International Journal of Applied Sciences and Smart Technologies}

Volume 3, Issue 2, pages 185-202

p-ISSN 2655-8564, e-ISSN 2685-9432

depart from Ratulangi Street Fire Department Headquarters. The path found by Dijkstra's algorithm is as follows:

Mabes Pemadam $\rightarrow$ jln ratulangi (depan wisma kalla) $\rightarrow$ persimpangan jln jend. sudirman $\mathrm{x}$ jln sungai saddang lama $\rightarrow$ persimpangan jln jend. sudirman $\mathrm{x}$ jln kartini $\rightarrow$ jln ahmad yani (sekitar mtc) $\rightarrow$ jln jend. m. jusuf $\rightarrow$ jln andalas $\rightarrow$ persimpangan jln ujung $\mathrm{x}$ jln yos sudarso $\rightarrow$ persimpangan jln yos sudarso $\mathrm{x}$ jln cakalang $\rightarrow$ jln cakalang $\rightarrow$ persimpangan $\mathrm{jln}$ cakalang $\mathrm{x}$ jln panampu $\rightarrow$ jln panampu.

From the results of the path search by the Dijkstra algorithm, it was found that there were two possible distance paths to the location of the fire on Jalan Panampu, the first was as far as 5068 meters with an estimated path and travel time of 7 minutes to get to the location of the fire which was on Jalan Panampu and departed from the Road Fire Department Headquarters. Ratulangi (Figure 7). The path found by Dijkstra's algorithm is as follows:

Mabes Pemadam $\rightarrow$ jln ratulangi (depan wisma kalla) $\rightarrow$ persimpangan jln jend. sudirman $\mathrm{x}$ jln sungai saddang lama $\rightarrow$ persimpangan jln jend. sudirman $\mathrm{x}$ jln kartini $\rightarrow$ jln ahmad yani (sekitar mtc) $\rightarrow$ jln jend. m. jusuf $\rightarrow$ jln andalas $\rightarrow$ persimpangan jln ujung $\mathrm{x}$ jln yos sudarso $\rightarrow$ persimpangan $\mathrm{jln}$ yos sudarso $\mathrm{x}$ jln cakalang $\rightarrow \mathrm{jln}$ cakalang $\rightarrow$ persimpangan $\mathrm{jln}$ cakalang $\mathrm{x}$ jln panampu $\rightarrow \mathrm{jln}$ panampu.
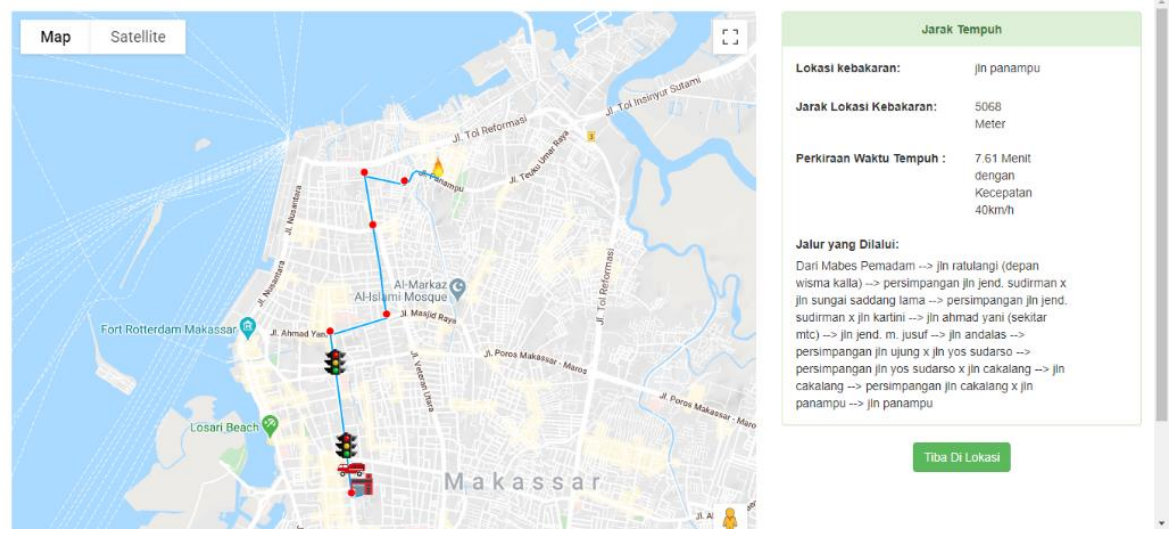

Figure 7. Search results for the first path to Jalan Panampu

The second route is 5287 meters with an estimated route and travel time of 7.94 minutes to get to the fire location on Jalan Panampu and depart from the Fire Department Headquarters Jalan Ratulangi (Figure 8). The path found by Dijkstra's algorithm is as follows: 


\section{International Journal of Applied Sciences and Smart Technologies}

Volume 3, Issue 2, pages 185-202

p-ISSN 2655-8564, e-ISSN 2685-9432

Mabes Pemadam $\rightarrow$ jln ratulangi (depan wisma kalla) $\rightarrow$ persimpangan jln jend. sudirman $\mathrm{x}$ jln sungai saddang lama $\rightarrow$ persimpangan $\mathrm{jln}$ jend. sudirman $\mathrm{x}$ jln kartini $\rightarrow$ $\mathrm{j} l n$ ahmad yani (sekitar mtc) $\rightarrow$ jln jend. $\mathrm{m}$. jusuf $\rightarrow$ persimpangan jln jend. m. jusuf $\mathrm{x}$ jln veteran utara $\rightarrow$ jln bandang $\rightarrow$ persimpangan $\mathrm{jln}$ bandang $\mathrm{x}$ jln ujung $\rightarrow$ persimpangan $\mathrm{jln}$ ujung $\mathrm{x}$ jln yos sudarso $\rightarrow$ persimpangan $\mathrm{jln}$ yos sudarso $\mathrm{x}$ jln cakalang $\rightarrow$ jln cakalang $\rightarrow$ persimpangan jln cakalang $\mathrm{x}$ jln panampu $\rightarrow$ jln panampu

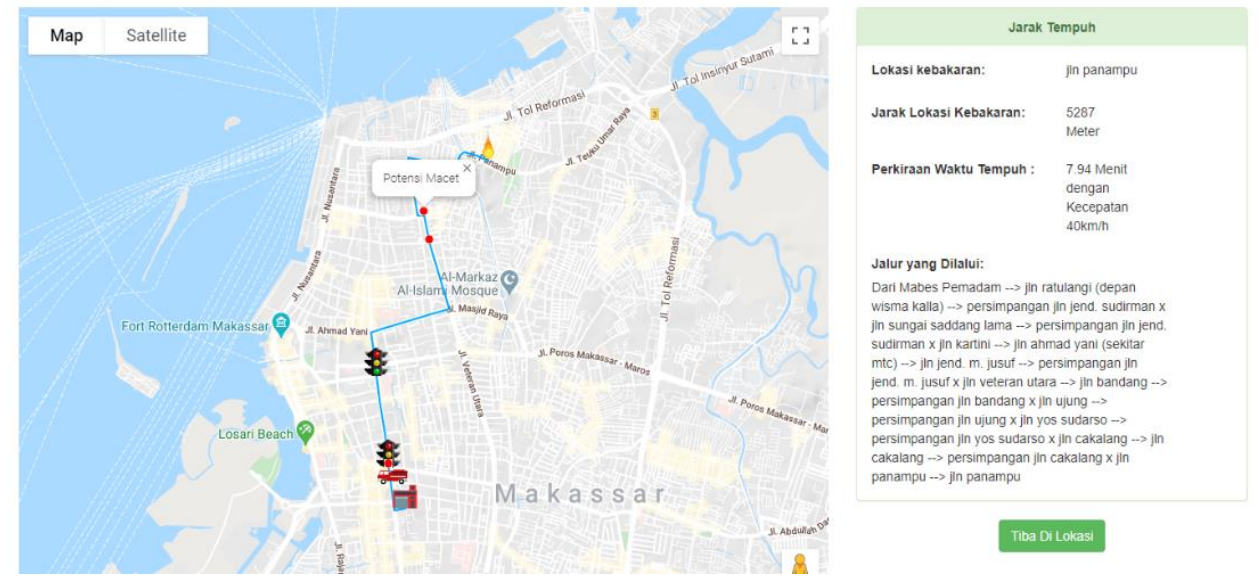

Figure 8. Search results for the second path to Jalan Panampu

The difference in the results of this path search is due to the different weights obtained in each lane that allows fire vehicles to pass when heading to the location of the fire on Jalan Panampu. The weight in question is the distance of each connected node from the starting point, namely the Pemadam Headquarters to the location of the fire on Jalan Panampu and also the value of traffic density which is assumed to be in the range 0-100. So that when there is a determination of a different path then on another path there is a higher traffic density value than the other lane or it can be said that on another path there is congestion so the dijkstra algorithm will choose a path with a low density value with a low distance also.

\section{User Interface}

The user interface for the firefighters can be seen in Figure 9. If there is a fire report there will be a warning. To enter the system, the fire squad leader can directly enter to view the map and the path that has been calculated by the Dijkstra algorithm along with the travel time. In addition, when the firefighters enter the map page, the status of the nearest traffic light on the vehicle on the path to be traversed will be changed to green. When the firefighters get a fire report and start leaving for the fire location, the 


\section{International Journal of Applied Sciences and Smart Technologies}

Volume 3, Issue 2, pages 185-202

p-ISSN 2655-8564, e-ISSN 2685-9432

firefighters leader can press the "GO" button to start the process of calculating the estimated travel time needed for vehicles to pass traffic lights that are on the path to be traversed. In addition, the path display on the map will be displayed based on the calculation results of the Dijkstra algorithm. For lighting settings, the vehicle coordinates in this study use coordinate simulation in Javascript. In this study, traffic lights are located at two points, namely point A which is at the intersection of Jend. Sudirman with Saddang Lama River road or at coordinates -5.14528510434342, 119.41523463271892. And point B which is at the intersection of Jend. Sudirman by Amampanga Street or at coordinates $-5.13698889347666,119.41410191337218$.

When the firefighter's vehicle starts walking towards the location of the fire, the GPS simulation of the vehicle will begin to be sent and the vehicle's coordinates will begin to be calculated the distance to the traffic light that is in the path that will be passed by the firefighter's vehicle to the location of the fire. When the coordinates of the vehicle have passed the coordinates of the nearest light, the light will return to its normal status and the next closest light will turn green to give priority to the fire engine when it comes to the fire location. When the fire department vehicle has arrived at the fire location, the team leader can press the Arrive at Location button to indicate that the firefighters have arrived at the fire scene. When the firefighters have finished extinguishing the fire, the team leader can press the Handled button to notify the system that the fire has been controlled and the fire status in the database is Handled.

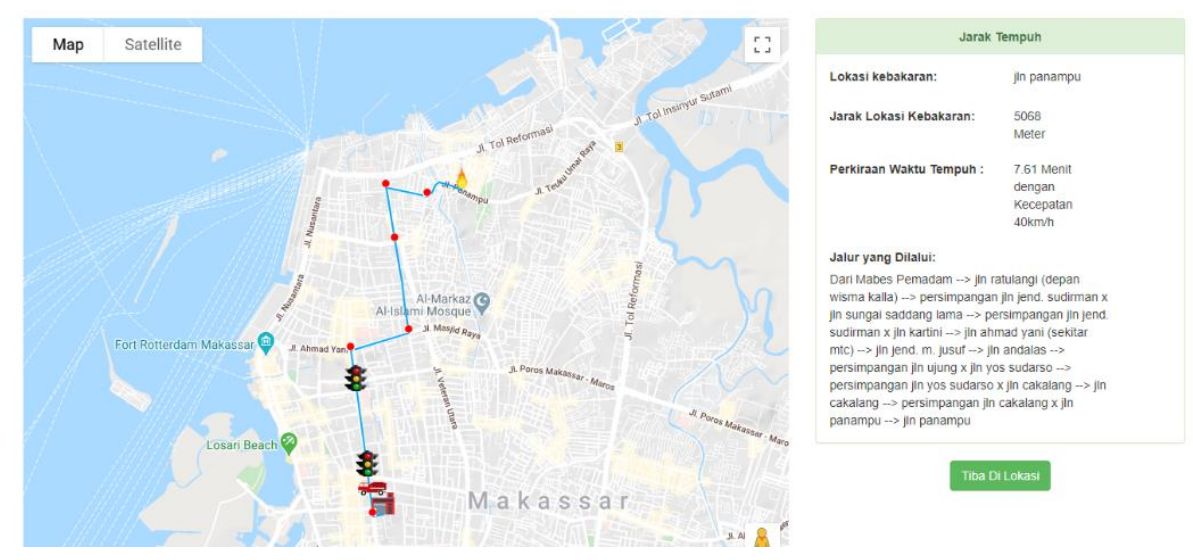

Figure 9. User Interface for Firefighters Squad 


\section{International Journal of Applied Sciences and Smart Technologies}

Volume 3, Issue 2, pages 185-202

p-ISSN 2655-8564, e-ISSN 2685-9432

\section{Simulation Testing}

In the results of the Traffic Signal Preemption simulation design, the system is made to adjust the color of the traffic lights that will be passed by fire vehicles. Traffic Signal Preemption Simulation using Wemos will capture the results of calculations between vehicle GPS simulation data and traffic light point data on the path that will be traversed by the fire to the location of the fire. Each Wemos will be given coordinates according to the coordinates of the traffic lights, which in this case the traffic lights are located at two points, namely point A which is at the Jend. Sudirman with Saddang Lama River road or at coordinates $-5.14528510434342,119.41523463271892$. And point B which is at the intersection of Jend. Sudirman by Amampanga Street or at coordinates 5.13698889347666, 119.41410191337218.

Wemos which will connect to the server will read the led.json file sent by the GPS simulation file and contain the coordinates of the lights which will be changed to the priority of the fire department. Next Wemos will read a json file containing the coordinates of the traffic lights that will be prioritized. The coordination of the lights in the data sent to Wemos is the same as certain Wemos coordinates, then Wemos with the coordinates sent will change the lights from a normal state to a priority for firefighting vehicles so that vehicles on the path to be traversed by fire vehicles will be able to run well. there are vehicles on the path that will be traversed by firefighters. See Figure 10.
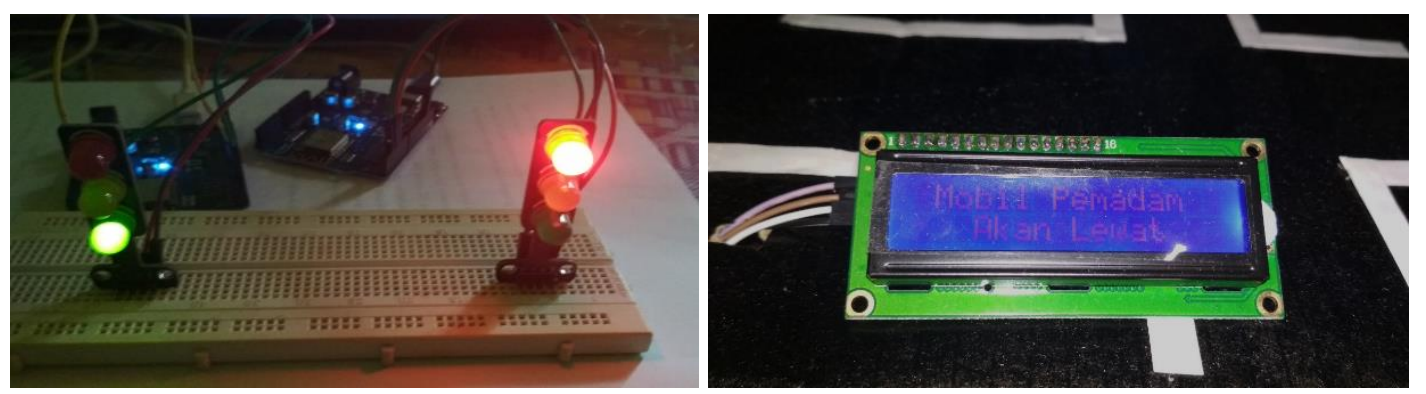

Figure 10. Lamp and LCD on Priority Condition

When the light status changes to priority, Wemos D1 takes a fraction of a second to read the led.json file until it changes the color of the lane 1 light to green and the lane 2 


\section{International Journal of Applied Sciences and Smart Technologies}

Volume 3, Issue 2, pages 185-202

p-ISSN 2655-8564, e-ISSN 2685-9432

light to red at the traffic lights at points A and B. In addition, the I2C LCD also displays the words notice that a fire engine is about to pass. When the coordinates of the nearest traffic light have been traversed by the fire vehicle heading to the location of the fire, the next light closest to the coordinates of the fire engine will be the priority and the previous light will return to its normal situation. And when the fire brigade has arrived at the scene of the fire, the last light will also return to its normal status.

From the light change test, it can be seen that the traffic lights A and B can run well in manual mode, where the red, yellow and green lights run alternately. The traffic lights at points A and B can only change automatically when the vehicle simulation starts. At points $A$ and $B$ there are 2 lights each, each of which will change color where the first light at point A will turn green while light 2 will turn red, as well as the two lights at point B. When the vehicle approaches the nearest light, the lights will turn red. becomes a priority, for example, if the vehicle simulation approaches the point A light, one light will turn green while the second light will turn red. The light that turns green is the path that will be traversed by the fire fighting vehicle, when the GPS simulation of the vehicle has passed the coordinates of the lights at point $\mathrm{A}$, the lights at point $\mathrm{A}$ will return to their normal status. Then the next closest light, namely the light at point $\mathrm{B}$, will turn green on the path to be traversed and on the other side of the road the lights will turn red until the vehicle has passed the coordinates of the red light at point B. changes quickly because Wemos depends on the speed of the connected internet to read json files on the server.

\section{Implementation Testing}

The author has carried out implementation tests carried out with program demonstration activities and also used the interview method to the Head of the Operational Section of the Makassar City Fire Department. The results of interviews and demonstration activities carried out with resource persons indicate that:

1. The functions in the application for fire admins have been running well according to needs, but it is hoped that there will be development so that it does not only include 


\section{International Journal of Applied Sciences and Smart Technologies}

Volume 3, Issue 2, pages 185-202

p-ISSN 2655-8564, e-ISSN 2685-9432

fire reports but several other types of reports such as animal disturbance reports, rescue of people or animals, and others.

2. The simulated Traffic Signal Preemption simulation is considered to be very good and is considered to be able to help the firefighters because there is a path to get to the fire location and for traffic lights it can help because it can make fire engines run without interference at crossroads where there are traffic lights. and minimize the possibility of crossing accidents when trying to break through traffic lights.

3. If it is to be implemented, collaboration with several relevant agencies in the Makassar city area is needed, namely the Makassar City Communications and Information Service Office, the Makassar City Transportation Service and South Sulawesi Province, and the Makassar City Health Office.

The conclusion that can be drawn from this implementation test is that the system created has been able to run well and is said to be able to help the performance of the Makassar City Fire Department, especially for handling fires that require handling speed. In addition, it is hoped that there will be development of applications for input from the admin side so that they can not only input fire reports but several other types of reports. In addition, collaboration with several agencies will be needed so that it can be implemented properly.

\section{Conclusion}

Traffic Signal Preemption simulation using GPS and Dijkstra's algorithm for emergency response to fire handling at the Makassar City Fire Service which is designed to help the performance of the firefighters. Where the Traffic Signal Preemption simulation has been able to adjust the color of the traffic lights when the GPS simulation of the fire vehicle approaches the traffic light coordinates and gives priority to the fire vehicle. Meanwhile, the fire emergency application to find the shortest path to the fire location along with the estimated travel time using the Dijsktra algorithm has been able to find the shortest path to the fire location. 


\section{International Journal of Applied Sciences and Smart Technologies}

Volume 3, Issue 2, pages 185-202

p-ISSN 2655-8564, e-ISSN 2685-9432

In this study, testing has not been carried out on the condition of changing lanes in real time. Future research is expected to accommodate changes in real time paths and also use a more optimal route determination algorithm.

\section{References}

[1] Ferdiansyah dan A. Rizal, "Penerapan Algoritma Dijkstra untuk Menentukan Rute Terpendek Pembacaan Water Meter Induk PDAM Tirta Kerta Raharja Kabupaten Tangerang”. Jurnal TICOM, 2 (1), 51-57, 2013.

[2] A. S. Girsang, “Algoritma Dijkstra.” (Online) (https://mti.binus.ac.id/2017/11/28/algoritma-dijkstra/, diakses 10 November 2018).

[3] A. Ratnasari, F. Ardiani, dan F. Nurvita, "Penentuan Jarak Terpendek dan Jarak Terpendek Alternatif Menggunakan Algoritma Dijkstra Serta Estimasi Waktu Tempuh.” Seminar Nasional Teknologi Informasi dan Komunikasi Terapan, 29-34, 2013.

[4] Iswanjono dan G. I. Wijaya, "Automatization Of Traffic Light For imergency Vehicles.” Jurnal Ilmiah Widya Teknik. 14 (2), 49-56, 2015.

[5] A. G. J. W. Aquarizky, B. Irawan, dan C. Setianingsih, " Perancangan Dan Implementasi Aplikasi Pencarian Rute Optimal Untuk Pemadam Kebakaran Berbasis Android Menggunakan Algoritma Floyd-Warshall." e-Proceeding of Engineering, 4 (3), 3993-4000, 2017.

[6] D. S. Septifany, A. Laila, dan M. Awaluddin, “Analisis Optimalisasi Rute Pemadam Kebakaran Berdasarkan Area Cakupan Pipa Hidran Di Kota Semarang.” Jurnal Geodesi Undip, 6 (3), 28-36, 2016.

[7] H. R. Al-Zoubi, B. A. Mohammad, S. Z. Shatnawi, dan A. I. Kalaf, "A Simple and Efficient Traffic Light Preemption by Emergency Vehicles using Cellular Phone Wireless Control." Mathematical Methods and Techniques in Engineering and Environmental Science, 167-170, 2011.

[8] J. F. Paniati, “Traffic Signal Preemption For Emergency Vehicles Traffic Signal Preemption For Emergency Vehicles A Cross-Cutting Study A Cross-Cutting Study," First Edition. ITS Joint Program Office, 2006. 
International Journal of Applied Sciences and Smart Technologies

Volume 3, Issue 2, pages 185-202

p-ISSN 2655-8564, e-ISSN 2685-9432

[9] Y. Yuniati, M. Ulvan, and M. Azzarah, 'Implementasi Modul Global Positioning System (GPS) Pada Sistem Tracking Bus Rapid Transit (BRT) Lampung Menuju Smart Transportation.” Jurnal Sains, Teknologi dan Industri, 14 (2), 150-156, 2017.

[10] Kadir. A., "Pengenalan Sistem Informasi," Penerbit ANDI, Yogyakarta, 2003. 